\title{
Developing High Quality Human Resources Of High-Tech Agricultural Enterprises In Vietnam
}

\author{
MA. Le Thi Hien \\ Thuong Mai University \\ hien.1t@tmu.edu.vn
}

\begin{abstract}
Globalization and Industrial revolution 4.0 impact increased to the businesses in general and agricultural hightech enterprises in particular. Businesses focus on applying high technology to improve efficiency in production, business activities and create a sustainable competitive advantage for businesses. Therefore, the human factor, especially the development of high-quality human resources for high-tech agricultural enterprises, should be concerned and play a decisive role. This paper focuses on analysing the current situation of developing high-quality human resources through Recruitment and Selection, Training and Development and Compensation of enterprises. The results show that the above activities still have many limitations, especially Recruitment, Selection and Compensation. From there, the author proposes some suggestions to improve the development of quality human resources of hightech agricultural enterprises in Vietnam.
\end{abstract}

Index Terms - high quality human resource, developing high quality human resources, high-tech agricultural enterprises.

\section{INTRODUCTION}

$\mathrm{H}$ IGH quality human resources are always the driving force of socio-economic development. In Vietnam, at the Resolution of the thirteenth Party Congress, it was stated that "Developing human resources, especially high-quality human resources, prioritize the development of human resources for leadership, management and key fields on the basis of improving and creating a strong, comprehensive and fundamental change in the quality of education and training, recruitment and selection, use and treatment of talents...".

Nowadays, many businesses and organizations have invested in developing high-quality human resources. That is a way to increase the scale, improve the quality and ensure the suitability of the human resource structure, especially in the context of the rapidly growing pace of science and technology development. Human resources must regularly update knowledge, skills, and expertise to operate new production technologies.

In the field of agriculture, developing high-tech agriculture is one of the important tasks in the socio-economic development strategy of our country today. The government issued many policies to encourage businesses to invest in agriculture, especially in high-tech agriculture. Agricultural enterprises are identified as playing the role of "pillars" in promoting the development of agricultural production of our country, towards commodity production, improving the competitiveness of Vietnamese agricultural products. Vietnam aims to develop about 200 high-tech agricultural enterprises by 2030. To do this, besides meeting the criteria to be recognized as a high-tech agricultural enterprise such as labor productivity, research activities, high-tech application testing, or total revenue of the enterprise, ... The factor of the enterprise's labor force must have a bachelor degree or higher to directly conduct research and development out of the total number of employees of the enterprise is at least $2.5 \%$. Therefore, those enterprises need to concentrate on developing quality human resources.

The research content of the article is the actual situation of human resource development activities. This article will has 5 mains parts: (1) Introduction; (2) Literature review; (3) Methodology and data; (4) Result \& discussion; (5) Conclusions and Recommendation.

\section{Literature REVIEW}

\section{A. High - tech agricultural enterprise}

High-tech agricultural enterprise is one of three forms of hi-tech management organization today. Developing hightech agricultural enterprise is a new development trend of agriculture in order to encourage enterprises to invest in agriculture and rural areas; bring high labor productivity to society

High-tech Law number 32/VBHN-VBQH gave the definition of high-tech agricultural enterprise. It is an enterprise applying high technology in the production of agricultural products with high quality, productivity and added value [1]. In addition, the law also specifies criterias for an high-tech agricultural enterprise. The enterprise must meet all the conditions:

+ High-tech applications on the list of high technologies prioritized for development investment specified in Article 5 of the Law (including the following fields: Information technology; Biotechnology; New material technology; Technology automation) for the production of agricultural products

+ To create agricultural products of high quality, productivity, value and efficiency, the enterprise's revenue from hitech applied agricultural products must reach at least $60 \%$ of the total annual net revenue.

+ Having research and testing activities on the application of high technology to produce agricultural products, to total expenditure on research and development activities carried out in Vietnam, the total annual net revenue reaches at least $0.5 \%$. The number of employees with professional qualifications from university or higher who directly conduct research and development out of the total number of employees of the enterprise is at least $2.5 \%$

+ Applying environmentally friendly and energy-saving measures in production and quality control of agricultural products up to Vietnam's standards and technical regulations. 
High-tech agricultural enterprises that fully meet the above conditions are entitled to: enjoy the highest incentives in accordance with the provisions of the law on land, corporate income tax, value-added tax, and export tax; be considered for funding for research, testing, training and technology transfer from the funding of the National High-tech Development Program.

In the dictionary of the Market Economy: "High quality human resources are those who have a certain level of knowledge, expertise, ability and skill with their own creative work in practical conditions. It can contribute to the development of society and of humanity" [9].

High quality human resource in the period of industrialization and modernization includes leaders and managers; scientific and technological staffs - those who have university or college degrees or higher and a group of skilled technical workers [7].

\section{B. Developing high quality human resources}

Developing high quality human resources plays an extremely important role and is the driving force for socio-economic development. High quality human resource development is also associated with the human resource development of society, but focuses on exploiting brainy labor with high skill level, capable of meeting the requirements of international economic integration and industrial revolution 4.0 (Nguyen Phan Thu Hang, 2015).

In the ILO's view on labor, "the development of high quality human resource is not only about skillful occupation but also of capacity development, which is to make people have the need to use that capacity to advance to get a good job as well as satisfy the career and personal life".

Developing high-quality human resources is the process of creating a change in quantity, improvement of quality and restructuring of a high-quality human resource group in order to meet business requirements and operational efficiency and organizational development.

There are 3 evaluation criteria for the developing high quality human resource

(1) Evaluation criteria for developing the quantity of high quality human resources: expressed through the increase in quantity and growth rate over the years, through the stages of high quality human resources.

(2) Evaluation criteria for developing the quality of high quality human resource: expressed through the level of education, expertise, skills and health of employees

(3) Criteria for the structure of high quality human resources to meet the production and business requirements: structure of human resources according to the professional and technical qualifications over the years; structure of management staff according to the qualifications over the years.

\section{Requirements on the capacity of workers in high-tech agricultural enterprises}

Human resources are a special resource that plays a decisive role in the success or failure of an organization. In order to develop human resources, it is necessary to evaluate the internal capacity of employees. Lucia and Lepsinger (1999) argued that competency models describe a particular combination of knowledge, skills and personal characteristics required to effectively perform a task in the organization and are used as an effective tool for selection, training and development, employee evaluation and human resource planning. According to the competency model of Bass BM (1990), competency standards include an individual's attitude, skills, and knowledge necessary to undertake a specific job position. This is a very popular model in human resource management to develop personal capacity.

In the period of industrialization, modernization and international integration, along with the scientific and technological revolution, especially the 4.0 industrial revolution taking place on a global scale, high-tech development agriculture is considered the right step to achieve the set goals. It requires a highly skilled workforce, proficient in the application of scientific and technical advance... to create economic efficiency. The competency of employees is reflected in the following aspects:

(i) Knowledge: the high-tech agriculture industry has a characteristic that focuses on the field of information technology; biotechnology; new material technology; automation technology for the production of agricultural products. Besides, science and technology are constantly changing. Therefore, in addition to the knowledge that workers are trained at specialized facilities, workers in agriculture 4.0 need practical knowledge to keep up with the trend as well as create new products of higher quality.

Besides professional knowledge, having legal knowledge is also very important. The global economy is opening up great opportunities for Vietnamese businesses to access markets around the world; goods are exchanged between countries more; it's the reason for increased complexity in international trade. In addition to current legal documents such as the High Technology Law 2019; the Enterprise Law 2020; the Commercial Law 2005; the Law on Import and Export Tax 2016... requires that human resources in the high-tech agriculture industry know the international laws and treaties when conducting transactions with foreign companies.

(ii) Skill: The ability to apply information technology well at work is a necessary requirement in the current digital technology. With the application of technology in production, it is required that human resources in the agricultural industry 4.0 need knowledge of science and technology, and know how to apply in work to work effectively.

In addition, foreign language skills also need attention and importance. Because, the trend of globalization requires the exchange of goods between countries in the world. The working environment will not only be limited to a single country, but also expand globally. Therefore, current highquality human resources must regularly use foreign languages, contact foreign partners to learn experience, bid and sell products to foreign partners. They must constantly improve their foreign language skills, especially English, in order to meet the requirements of each job.

(iii) Attitude: They are people who are always self-learning, self-development and desire to perfect themselves; curious, creative thinking to discover problems and find ways to solve them. In addition, employees need to be disciplined and professional in their work. It is a basic condition to help improve labor productivity, help employees to have the abil- 
ity to advance, and fight bad habits that are barriers to personal development.

\section{Methodology And Data}

\section{A. Data collection methods}

\section{1) Documentary research methods}

Secondary data is collected and aggregated from studies and reports of organizations and agencies, such as: Association of Advanced Technology Enterprise in Agriculture (ATE), Ministry of Agriculture and Rural Development, Ministry of Planning and Investment Portal, General Statistics Office of Vietnam, High-tech agricultural enterprises... These documents are synthesized, analyzed and compared to find out the characteristics, strengths and weaknesses of human resources in agriculture.

\section{2) Survey method}

The survey questionnaire is used for the purpose of collecting survey information on the quantity and quality of human resources of high-tech agricultural enterprises. The author sent to managers, administrative staff, agricultural engineers, and workers. In order to ensure the representativeness of the study, the author tried to collect as many questionnaires as possible. 800 questionnaires were distributed and 696 valid votes were collected, accounting for $87 \%$ of the total number of votes.

\section{B. Methods of processing and analyzing data methods}

Based on primary and secondary data collected, the research conducted data cleaning, information coding in the survey questionnaire data, entries and processed by SPSS software.

\section{Result AND Discussion}

\section{A. The situation of high quality human resource of high- tech agricultural enterprises}

According to the report of the Ministry of Agriculture and Rural Development, from December 2011 to April 2020, there were 66 enterprises recognized as high-tech agricultural enterprises; in which, there were 20 enterprises in the field of cultivation, 25 enterprises in the field of fisheries, 21 enterprises in the field of animal breeding. However, according to regulations, the certificate of high-tech agricultural enterprises in Vietnam is valid for 5 years. After that, enterprises must apply for re-issuance of the certificate if they are eligible. Therefore, in December 2020, in Vietnam, there were 46 enterprises whose certificates are still valid, and these enterprises still enjoy the benefits under the provisions of the High Technology Law.

Through the above table, the number of human resources of high-tech agricultural enterprises has increased over the years. About gender, due to the specificity of agriculture, the percentage of female workers in high-tech agricultural enterprises accounts for the majority (about 60\%). Female workers are characterized by industriousness, diligence, meticulousness and ingenuity, so they are suitable for jobs requiring diligence such as production in line, with high specialization. About the professional qualifications, workers at high-tech agricultural enterprises have a low percentage of employees trained in technical qualifications, mainly still
Table 1. Human Resource Statistics of High-Tech Agricultural ENTERPRISES

\begin{tabular}{|c|c|c|c|c|c|}
\hline & 2016 & 2017 & 2018 & 2019 & 2020 \\
\hline $\begin{array}{l}\text { Total number of } \\
\text { employees }\end{array}$ & 10356 & $\begin{array}{c}1132 \\
8\end{array}$ & 12469 & $\begin{array}{c}1349 \\
1\end{array}$ & 13803 \\
\hline $\begin{array}{l}\text { Gender: } \\
\text { - Male } \\
\text { - Female }\end{array}$ & $\begin{array}{l}3841 \\
6515\end{array}$ & $\begin{array}{l}4101 \\
7227 \\
\end{array}$ & $\begin{array}{l}4691 \\
7778 \\
\end{array}$ & $\begin{array}{l}4797 \\
8694\end{array}$ & $\begin{array}{l}4980 \\
8823\end{array}$ \\
\hline $\begin{array}{l}\text { Trained in technical } \\
\text { qualifications } \\
\text { (1) Skilled and } \\
\text { technical workers }\end{array}$ & 2721 & 3315 & 3860 & 3990 & 4057 \\
\hline - University or higher & 687 & 882 & 1038 & 1099 & 1214 \\
\hline - College & 762 & 926 & 1078 & 1179 & 1235 \\
\hline - Intermediate level & 758 & 920 & 1152 & 1191 & 1130 \\
\hline - Elementary level & 514 & 587 & 592 & 521 & 478 \\
\hline $\begin{array}{l}\text { (2) No trained in } \\
\text { technical qualifications }\end{array}$ & 7635 & 8013 & 8609 & 9501 & 9746 \\
\hline
\end{tabular}

(Source: Enterprises' report - Ministry of Agriculture and Rural

$$
\text { Development) }
$$

human resources without technical qualifications. The number of workers without technical qualifications is concentrated on the number of workers who are directly engaged in agriculture; there are very few people who have been trained in schools.

For high-quality human resources, based on the High Technology Law, the criteria for recognition of high-tech agricultural enterprises and the results of interviews with managers, it is found that the human resources have a college degree or higher and a good health according to decision No. 1613/QD-BYT reaching grades 1 and 2 who is eligible to meet the requirements of high-quality human resources of high-tech agricultural enterprise.

The workforce at high-tech agricultural enterprises can be divided into 4 main groups: managers, administrative staff, agricultural engineers, and workers. In which, workers have the largest number with an average number of employees of $79 \%$. They are mainly people directly involved in production activities of enterprises, this is also the position with the most fluctuations. They work in farms, product processing factories, so the demand for recruiting human resources for this position is also more.

\section{B. The actual content of developing high quality human resource of high-tech agricultural enterprises in Vietnam}

1) Developing a high quality human resource of hightech agricultural enterprises through recruitment and selection

Recruitment and selection is the first step that determines the quality of human resources in high-tech agricultural enterprises in Vietnam. High-tech agricultural enterprises have a need to recruit and select many agricultural engineers. There are many businesses, including large corporation that need a lot of human resources in this field. Many businesses have linked to colleges and universities to recruit, even "order students" to to work for the company after graduation. According to the study, high-tech agricultural enterprises use many sources for recruitment. In which, recruitment source through training facilities such as colleges, universities is curently chosen by many companies. During the training period, the company will create conditions for students to practice at the company, so they can grasp the technology and understand the professions that they will join later. 
The specific survey results on evaluation recruitment and selection activities of high - tech agricultural enterprises are show in the table below.

Table 2. The Result On Evaluating Recruitment Selection

\begin{tabular}{|c|c|c|c|}
\hline No. & Criteria & Mean & $\begin{array}{l}\text { Standard } \\
\text { Deviation }\end{array}$ \\
\hline TD1 & $\begin{array}{l}\text { The company's policy of } \\
\text { recruitment and selection } \\
\text { ensures high science }\end{array}$ & 2.84 & 0.890 \\
\hline TD2 & $\begin{array}{l}\text { Selection criteria are } \\
\text { clearly and objectively } \\
\text { defined }\end{array}$ & 3.48 & 0.938 \\
\hline TD3 & $\begin{array}{l}\text { The person being } \\
\text { recruited is qualified and } \\
\text { capable to perform the } \\
\text { job }\end{array}$ & 3.01 & 0.908 \\
\hline TD4 & $\begin{array}{l}\text { The current policies of } \\
\text { enterprises to attract, } \\
\text { arrange and use laborers } \\
\text { are reasonable }\end{array}$ & 2.77 & 0.936 \\
\hline
\end{tabular}

Employees' evaluation of the recruitment and selection of enterprises is only average. This is also consistent with the study on recruitment sources of high-tech agricultural enterprises today, when most enterprises use the source associated with universities and colleges in "ordering" graduates. There is no diversification through external recruitment source. Besides, for new graduated student, the recruited people still need to be retrained in practical job knowledge and skills. So, the person being recruited is not enough qualified and capable to perform the job.

2) Developing a high quality human resource of high-

tech agricultural enterprises through training and

development

Training is considered an effective measure to improve the quality of high-quality human resources in enterprises, thereby turning the established goals and implementation plans of enterprises into reality. The result on evaluating training and development of high-tech agricultural enterprises is shown as below

Table 3. The Result On Evaluating Training And Development

\begin{tabular}{|c|c|c|c|}
\hline No. & Criteria & Mean & $\begin{array}{c}\text { Standard } \\
\text { Deviation }\end{array}$ \\
\hline DT1 & $\begin{array}{c}\text { The training needs are } \\
\text { identified as realistic, useful } \\
\text { and based on the } \\
\text { organization's business } \\
\text { strategy }\end{array}$ & 3.36 & 0.867 \\
\hline DT2 & $\begin{array}{c}\text { Employees in each job } \\
\text { undergo annual training } \\
\text { programs }\end{array}$ & 3.37 & 0.953 \\
\hline DT3 & $\begin{array}{c}\text { Training and development } \\
\text { programs for employees in } \\
\text { enterprises have a good } \\
\text { quality }\end{array}$ & 3.83 & 0.836 \\
\hline DT4 & $\begin{array}{c}\text { Employees have many } \\
\text { opportunities for advancement } \\
\text { in the company }\end{array}$ & 3.43 & 0.947 \\
\hline DT5 & $\begin{array}{c}\text { The promotion policy of the } \\
\text { enterprise is fair }\end{array}$ & 3.84 & 0.894 \\
\hline
\end{tabular}

Training and development activities of high-tech agricultural enterprises have achieved a good level. In which, identifying training needs is important in the process of training and developing human resources. However, the training needs are evaluated with the lowest average score. For the program and methods of training and development. Enterprises focus on training programs on knowledge and skills related to current jobs. In addition, enterprises also have training programs on occupational hygiene and safety, knowledge of laws and policies... which are updated and trained regularly. However, the frequency of employees training depends on the job position

- For workers, high-tech agricultural enterprises hire workers for positions that do not require a high level such as processing, care and animal husbandry areas. When new employees come in, enterprises use on-the-job training methods. Experienced employees or managers will guide and mentor new employees.

- For administrative staff, agricultural engineers, enterprises have long-term training plans for those employees, especially the agricultural engineer. The method is used for long-term training to improve professional qualifications such as sending to study abroad or domestically at universities and colleges.

- For managers, in order to do their job well, in addition to general management skills, managers need to have some specialized technical knowledge such as: production line management skills, product quality management skills.

The promotion for employees is good. The promotion, on the one hand, is based on working seniority and qualifications; on the other hand, based on the performance results of employees after training. This has helped employees to see opportunities for advancement. Currently, there are also quite a few high-tech agricultural enterprises that have performed this activity well, thereby helping to increase employee satisfaction with enterprises.

3) Developing a high quality human resource of hightech agricultural enterprises through compensation

\section{a) Direct Financial Compensation}

Because the majority of employees in high-tech agricultural enterprises are workers (accounting for 79\%) with low qualifications. Salary is their main source of income. In order to be able to maintain motivation for employees, improve their working performance and business efficiency of enterprises, enterprises have used financial policy as a necessary tool to achieve the above goals. Bonuses are a kind of positive material stimulation to help employees strive more at work.

In addition, allowances are also an important factor constituting the monthly income of employees. In high-tech agricultural enterprises, employees not only receive the usual allowances such as lunches and responsibility allowances, but also receive allowances for specific jobs according to the provisions of Circular 11/2020/TT-BLDT$\mathrm{BXH}$.

According to the survey results in Figure 2 above, the income of employees has a marked difference corresponding to their working position. For workers, the average salary is 5 million dong/month. For administrative staff, it is from 510 million dong/month. The average salary for agricultural engineers is higher, from 10-20 million dong/month. And for managers, it is above 20 million dong/month. The agricultural industry has more recruitment needs for the agricul- 


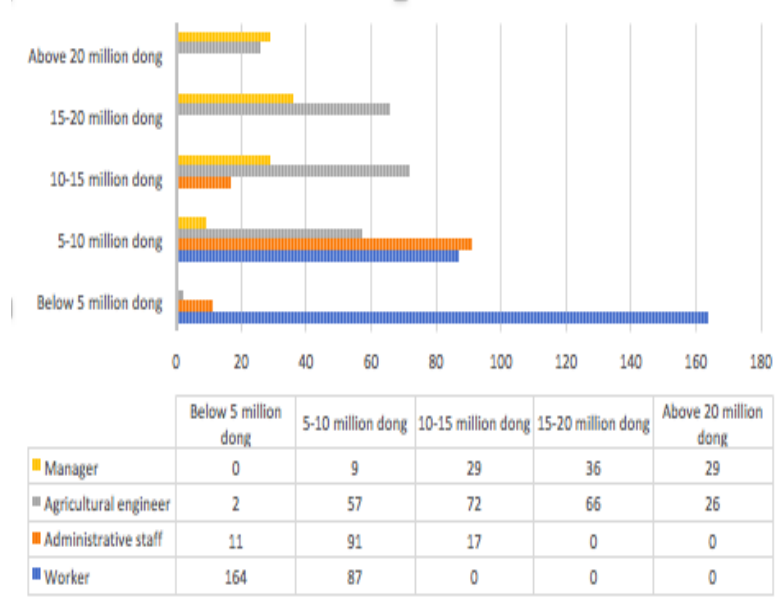

Figure 2. The income of employees in high-tech agricultural enterprises

tural engineer position, but the supply of high-quality human resources is low. Therefore, business often pay a favorable salary for this position in order to attract and recruit human resource as well as retain them.

\section{b) Non-financial Compensation}

Non-financial compensation is actually taking care of the spiritual life of employees through tools that are not money. The spiritual life needs of employees are diverse and increasingly demanding, such as: joy at work, excitement, passion for work, fair treatment, respect, communication with people, with colleagues. To demand those needs, enterprises need to have a good working environment for employees.

TABle 4. The Result On Evaluating Non-Financial Compensation

\begin{tabular}{|c|l|c|c|}
\hline No. & \multicolumn{1}{|c|}{ Criteria } & Mean & $\begin{array}{c}\text { Standard } \\
\text { Deviation }\end{array}$ \\
\hline MT1 & $\begin{array}{l}\text { Safe and comfortable working } \\
\text { conditions and time }\end{array}$ & 3.55 & 1.021 \\
\hline MT2 & Employees are treated fairly & 3.38 & 0.959 \\
\hline MT3 & $\begin{array}{l}\text { The relationship between } \\
\text { superiors and subordinated is } \\
\text { friendly and trustworthy }\end{array}$ & 3.21 & 1.028 \\
\hline MT4 & $\begin{array}{l}\text { The level of technology } \\
\text { (machinery and equipment) of } \\
\text { the enterprise is very modern }\end{array}$ & 3.66 & 0.916 \\
\hline MT5 & $\begin{array}{l}\text { In the enterprise, there is close } \\
\text { association and cooperation } \\
\text { between employees }\end{array}$ & 3.22 & 1.020 \\
\hline MT6 & $\begin{array}{l}\text { Workers work is not too } \\
\text { stressful }\end{array}$ & 3.40 & 0.957 \\
\hline
\end{tabular}

For high-tech agricultural enterprises, machinery and equipment are a new type with high productivity. Therefore, the products produced have high competitiveness and good productivity. Criteria of the level of technology of the enterprises is evaluated at the best level.

According to the provisions of the law, in order to ensure the safety and health of employees, the employer is responsible for fully equipping labor protection equipment, ensuring occupational safety and health, and improving the working conditions for employees. In high-tech agricultural enterprises, the safe and comfortable working conditions and working time achieved an average good score. Since then, safe and comfortable working conditions and time have created a working spirit for employees, making them feel not too pressured when working at the enterprise.

However, the relationship between superiors and subordinates, between employees, is assessed at an average level. So, enterprises need to have a policy to create relationships among members of the organization.

\section{Conclusions and Recommendations}

High-quality human resource is considered an important factor and the core for organizational development, increased competitiveness and long-term development in the future. Because of that, many businesses and organizations have invested in developing high quality human resources. That is a way to increase the scale, improve the quality and ensure the suitability of the human resource structure, especially in the context of the rapidly growing science and technology development. Human resources must regularly update knowledge, skills and expertise to operate new production technology. Hi-tech agricultural enterprises are no exception to this trend. When international integration, the current scientific and technological revolution 4.0 have strong impact, it is necessary to focus on developing high quality human resources. This study focuses on analyzing the situation of developing high quality human resources of hightech agricultural enterprises in Vietnam. In order to develop high quality human resource, some solutions as follows:

\section{The first, recruitment and selection}

This is the process to find the most suitable people, ensure the right number of employees for the job, reduce hiring costs, save time and a part of training costs. So, enterprises need to establish specific criteria in hiring policies, specific criteria for each job position. Depending on the actual situation of the enterprise, the number and positions for vacancy to recruit from internal or external sources. However, enterprises alway give priority to recruit inside the enterprise first. In case the enterprise is not enough or doesn't match the expertise and job requirements, the new enterprise should conduct recruitment from external sources.

Because labor in the high-tech agricultural sector is a scarce human resource, hi-tech agricultural enterprises can diversify their recruitment sources from foreigh workers. The policies and measures to recruit foreign workers with high professional and technical qualifications to perform key management and technical tasks in enterprises. This will also help internationalize and improve the qualifications of human resources at hi-tech agricultural enterprises.

\section{The second, training and development}

Human resource training and development has a significant impact on developing high-quality human resource of hi-tech agricultural enterprises in Vietnam. In order to develop the capacity to perform work for human resources in general and high-quality human resources in particular, training is considered a necessary and important activity to improve the quality of human resources of the organization. Faced with the requirement to improve productivity and product quality, hi-tech agricultural enterprises must invest in new technologies to keep up with the development trend and improve their competitiveness. Therefore, in order to 
build a capable and responsive staff compared to the competition, the training and development needs to have a good implementation plan. In which, the identification of training needs should be done well and according to the process; enterprises need to diversify forms of training, update the appropriate training program contents, organize training and conduct effective training evaluation.

Developing high-quality human resources requires high tech agricultural enterprises to have a development plan for their employees. Enterprises need to have specific plans on career development programs for employees. Regularly organizing career seminars, especially with new employees, will help them to see career opportunities clearly. Besides, enterprises need to build a lifelong learning environment in the workplace for human resources.

The third, compensation

High-tech agricultural enterprises need to have a compensation policy that is fair and consistent with work performance, each person's ability to work. At the same time, they need to strengthen material and spiritual incentives to motivate employees and to complete their work and strive to develop themselves. To do this, enterprises need to start from the achievements of employees in the enterprise. Enterprises should develop performance evaluation criteria for employees of each department and subordinate unit. 3P compensation policy can be applied, in which: P1: Position - pay for position; P2: Person - Pay for Person (Competency-based pay) and P3: Performance - Pay for performance

Diversify forms of bonuses for employees such as material rewards in cash according to work performance, initiative rewards, and rewards for completing goals at work. Reward and encouragement should be timely, with the right level of dedication, and should be determined as regular and continuous work.

A comfortable and safe working environment will create conditions for employees to complete their work better. Enterprises need to apply a reasonable and flexible working time regime, ensure facilities and working conditions for individuals; especially workers in the breeding and care areas, the processing area. Enterprises regularly check, improve and upgrade the quality of machinery, equipment to ensure safety and hygiene at work. High tech agricultural enterprises need to build more separate rest areas for employees to create conditions for them to live and rest at the workplace. Good resting conditions will help employees reduce stress and fatigue, improve health and fitness after every long working hour.

In addition to ensuring material life, ensuring spiritual life is also very important. It helps create peace of mind at work, stabilizing the mind during the working process, improving labor productivity and the employee commitment with enterprises.

\section{REFERENCES}

[1] Congress Office (2019), High Technology Law number 30/VBHN$\mathrm{VPQH}$

[2] Barber, A. E. (1998). Recruiting employees: Individual and organizational perspectives.

[3] L. Borghans, and B. Ter Weel, Computers, skills and wages, Applied Economics, vol. 35, no. 14, pp. 1561-1576.

[4] E. Berman, J. Bound, and S. Machin, Implications of skill-biased technological change: International evidence, Quarterly Journal of Economics, vol. 113, no. 4, pp.1244-1279, 1998.

[5] B. P. Cozzarin, and J. C. Percival, Complementarities between organisational strategies and innovation, Economics of Innovation and New Technology, vol. 15, no. 3, pp. 195-217, 2006.

[6] C. Francalanci, and H. Galal, Information technology and worker composition: Determinants of productivity in the life insurance industry, MIS Quarterly, vol. 22, no. 2, pp. 227-241, 1998.

[7] B. J. L. Landry, S. Mahesh, and S. Hartman, The changing nature of work in the age of e-business, Journal of Organizational Change Management, vol. 18, no. 2, pp. 132-144, 2005.

[8] S. Machin, and J. Van Reenen, Technology and changes in skill structure: Evidence from seven OECD countries, The Quarterly Journal of Economics, vol. 113, no. 1, pp. 1215-1244, 1998.

[9] Tabibi SJ, Khah SV, Nasiripour AA, Vahdat S, and Hessam S (2011). Factors affecting human resource development in the Iranian social security organization's hospitals. World Applied Sciences Journal, 15(2): 164-173.

[10] Thousand Oaks, CA: Sage Publications, Inc. Benmore, G., \& Palmer, A. (1996). Human resource management in small firms: Keeping it strictly informal. Journal of Small Business and Enterprise Development, 3(3), 109-118 